\title{
Trends of Water Requirements of Major Crops and Cropping Patterns in Bogura and Rajshahi Districts of Bangladesh
}

\author{
Mohammad A. Mojid ${ }^{1}$, Farhana Y. Shibly ${ }^{1} \&$ Tapos K. Acharjee ${ }^{1}$ \\ ${ }^{1}$ Department of Irrigation and Water Management, Bangladesh Agricultural University, Mymensingh, 2202, \\ Bangladesh \\ Correspondence: Mohammad A. Mojid, Bangladesh Agricultural University, Mymensingh, 2202, Bangladesh. E- \\ mail:ma_mojid@yahoo.com
}

Received: April 21, 2020 Accepted: May 3, 2020 Online Published: May 11, 2020

\begin{abstract}
Reliable past trends of water requirements of individual crops and cropping patterns at local level, although crucially important for irrigation forecast and agricultural planning, are yet inadequate for the water-scarce Barind region of Bangladesh. This study, therefore, determined water requirements and their trends of eight major crops (aus, aman, boro, vegetables, mustard, sugarcane, wheat and potato) and six cropping patterns (aus-aman-boro, aus-aman-potato, aman-potato-fallow, vegetables-aman, aman-mustard-fallow and aus-fallow-wheat) of Bogura and Rajshahi districts of the Barind region. Water requirements were determined from crop, soil and weather data for the period 1985-2013 by using Soil-Water Balance via CropWat (SWBcropwat) model. Trends of rainfall, crop evapotranspiration $\left(\mathrm{ET}_{\mathrm{c}}\right.$ ) and irrigation requirement (IR) were determined with MAKESENS statistical tool. Monthly total rainfall revealed increasing trend in January, August and October but decreasing trend in the other months, with significant $(\mathrm{p} \leq 0.05)$ trend in July in Bogura. Monthly total $\mathrm{ET}_{\mathrm{c}}$ decreased except in July and September, with significant trend in October-April/May. Seasonal $\mathrm{ET}_{\mathrm{c}}$ for the crops decreased significantly except for aman rice and sugarcane in Bogura and for aman rice in Rajshahi. $\mathrm{ET}_{\mathrm{c}}$ also decreased for the cropping patterns except for aman-mustard-fallow in Rajshahi. While effective rainfall (ER) for the crops and cropping patterns decreased only minimally, IR decreased significantly for boro, potato and vegetables in Bogura and for mustard and vegetables in Rajshahi. IR decreased for all cropping patterns, with significant trend for ausaman-potato, aman-potato-fallow and vegetables-aman patterns. In response to changing cropping area, total volume of $\mathrm{ET}_{\mathrm{c}}$ increased gradually from 1985 to 2005 in Bogura and from 1985 to 2010 in Rajshahi for boro rice, but it decreased until 2005 before increasing for aus rice in both districts. After the year 2000, total volume of $\mathrm{ET}_{\mathrm{c}}$ decreased for wheat but increased for potato, indicating a shift from wheat to potato cultivation. Due to contrasting trends of ER and $\mathrm{ET}_{\mathrm{c}}$ and self-motivated shift in crop-choice, continuous adjustment of irrigation-based crop planning is necessary. The results of this study can guide future investigation for all other crops and cropping patterns to help planning agriculture of the study areas by choosing appropriate crops and cropping patterns based on available water resources.
\end{abstract}

Keywords: irrigation forecast, water scarcity, agricultural planning, SWBcropwat

\section{Introduction}

Application of water and its managed usage has been an essential factor worldwide in raising productivity of crop agriculture and ensuring predictability in outputs. Crop-water requirement varies substantially across the globe, reflecting differences in cropping intensity, crop choice, soil characteristics, irrigation water availability, agricultural management and climatic condition. Information on crop-water requirement is important for selection of crops and cropping patterns and their irrigation scheduling in any particular area. When water is scarce, knowledge on the magnitude of water demand is crucial for decision-making about agricultural planning based on limited water resources.

Irrigated agriculture has become central to the current rapid agricultural development and food security in Bangladesh. Rice being the staple food is currently grown on $73.7 \%$ of the total cultivated land, constituting $93.4 \%$ of the total cereal production (BBS, 2017). The projected population in the country, 185 million in 2030 and 202 million in 2050 (United Nations, 2017), indicates an additional requirement of 12.4 and 21.0 million tons of rice respectively by 2030 and 2050 (Mainuddin \& Kirby, 2015). So, irrigation will remain critical in supplying foods (Peacock, 1996), and the consumption of agricultural water will continue to increase during the coming decades 
(CAWMA, 2007). Moreover, domestic and industrial usages of water are on the rise (Bindraban, 2001); these are likely to grow by $100 \%$ and $440 \%$, respectively by 2050 (BDP2100, 2017). So, there will be growing competitions for getting water among the various users. Furthermore, while climate change is likely to cause shortage of drinking and irrigation water (World Bank, 2015) in one hand, will increase demand of irrigation from less than $1 \%$ for 2030 in average condition to maximum 3\% for 2050 in dry condition (Kirby et al., 2016) on the other hand. Rainfall variability, although uncertain, featuring extreme high and low rainfall, is critical for agricultural productivity and water availability. Thus, water availability for future food security is challenging and will become more challenging if further increase in irrigated area takes place, especially in vulnerable areas like the Barind region of the North-West Bangladesh.

The Barind tract being one of the most intensive agricultural and irrigated regions in Bangladesh supplies about $35 \%$ of irrigated boro rice and $60 \%$ of wheat of the whole country. About $78 \%$ irrigated land in this region is covered by groundwater (Hasanuzzaman et al., 2017). Particularly, over $97 \%$ of the total area in Rajshahi district and over $99 \%$ of the total area in Bogura district of the Barind region are currently irrigated by groundwater (BBS, 2017); usage of surface water for irrigation is very limited in these districts because of its limited availability. The Barind region is facing a number of challenges, such as rapid population growth, declining cultivable land, inadequate water availability during dry season (October-April), declining groundwater table (Ahmad et al., 2014; Mojid et al., 2019) and extreme events like floods and droughts. Some parts of the Barind region are now of greatest concern over falling groundwater tables (CSIRO, WARPO, BWDB, IWM, BIDS, CEGIS, 2014) since groundwater usage has become unsustainable in those areas (Kirby et al., 2013). Impacts of climate change are now visible in the Barind tract in the form of temperature variations, erratic rainfall patterns with low monsoon rains, decreased duration of rainy season, intense short-duration rainfall, increased number of droughts, and prevalence of rough weather. Thus, availability of adequate water during farming seasons has become uncertain. Consequently, it has now become essential to understand the future possible changes in agricultural water requirements to improve water resources management in the region. Demand management is regarded as an important part of the overall solution of water scarcity. The importance of accurately estimating crop-water demand for irrigation forecast and agricultural water management has been widely recognized (Hossain et al., 2017) since proper plan for the application of desired amount of water at right time can conserve the water resources.

Trends of water requirement, estimated from the observed recent past long-term daily climate data, and their comparison with the trends of local climatic parameters may provide a better insight into the changes in water demand (Acharjee et al., 2017a). Water requirement and cropping patterns are very closely related and very important for efficacious crop production. If water requirements of each crop and cropping pattern of a region are known, agriculture of the region can be planned based on its available water resources. With this view, this study was planned to find out water requirements and contribution of effective rainfall to the total irrigation requirement, and their trends for the major crops and cropping patterns in Bogura and Rajshahi districts of the North-West Bangladesh over the recent past three decades (1985-2013).

\section{Methodology}

\subsection{Study Area}

The Barind tract of Bangladesh comprises most parts of the greater Dinajpur, Rangpur, Pabna, Rajshahi, Bogura, Joypurhat and Naogaon districts of Rajshahi and Rangpur divisions in the North-West Bangladesh (Fig. 1). About $73 \%$ of its land area is used for agriculture and the percentage of lands used for single cropping, double cropping and triple cropping is $15 \%, 56 \%$ and $29 \%$, respectively in Rajshahi division and $8 \%, 64 \%$ and $27 \%$, respectively in Rangpur division (BBS, 2017). A large variety of different crops are grown in these divisions. These include rice (aus, aman, boro), vegetables, mustard, sugarcane, wheat, potato, tobacco, fibres (jute, mesta, cotton), fruits (mango, pineapple, jackfruit, papaya, melon \& water melon, litchi, guava, lemon, palm, date), other cereals (barley, joar, bajra, cheena, kaon), oil seeds (sesame, mustard, groundnut, linseed, coconut, castor), pulses (gram, arhar, lentil, chick pea, mung bean, kheshari), and spices \& condiments (chillies, onion, garlic, turmeric, ginger, coriander). Of these, the major crops are rice (aus, aman and boro), wheat, potato, jute, sugarcane, mustard, maize and vegetables, most of which (except aman rice, jute and sugarcane) are cultivated during dry season (NovemberApril). Boro rice is the dominant dry period crop, which is cultivated on more than $70 \%$ of the cultivable area during December to May (Acharjee et al., 2017b).

The Barind tract lies in the monsoon region of the summer-dominant hemisphere. Its average temperature ranges from $25^{\circ} \mathrm{C}$ to $35^{\circ} \mathrm{C}$ in the hottest season and $9^{\circ} \mathrm{C}$ to $15^{\circ} \mathrm{C}$ in the coolest season (Banglapedia, 2014). The region is regarded as a drought-prone water-scarce area, often causing devastating effect on agricultural production and 
livelihood of the people (Hussain, 2017). Bogura and Rajshahi districts from the Barind tract (Fig. 1) were selected for this study. Bogura district has a humid sub-tropical climate, with average annual rainfall being $1610 \mathrm{~mm}$. The annual average temperature of the district varies from $11.9^{\circ} \mathrm{C}$ to $34.6^{\circ} \mathrm{C}(\mathrm{BBS}, 2014)$. Rajshahi has a tropical wet and dry climate. Rainfall is relatively low; the average annual rainfall being $1,448 \mathrm{~mm}$. The maximum mean temperature varies from 32 to $36^{\circ} \mathrm{C}$ during April to July, and the minimum temperature is 7 to $16^{\circ} \mathrm{C}$ in January (Wikipedia, 2018). There were total 177 cropping patterns in the greater Bogura regions (Bogura and surrounding districts), with the highest number of cropping patterns (36) was in Nandigram upazila and the lowest number (6) was in Dupchachia and Kahalu upazila of Bogura district (Islam et al., 2017). In the greater Rajshahi region (Rajshahi and surrounding districts), there were total 172 cropping patterns, with the highest number (36) in Paba upazila and the lowest number (11) in Charghat (11) upazila of Rajshahi district (Rashid et al., 2017).

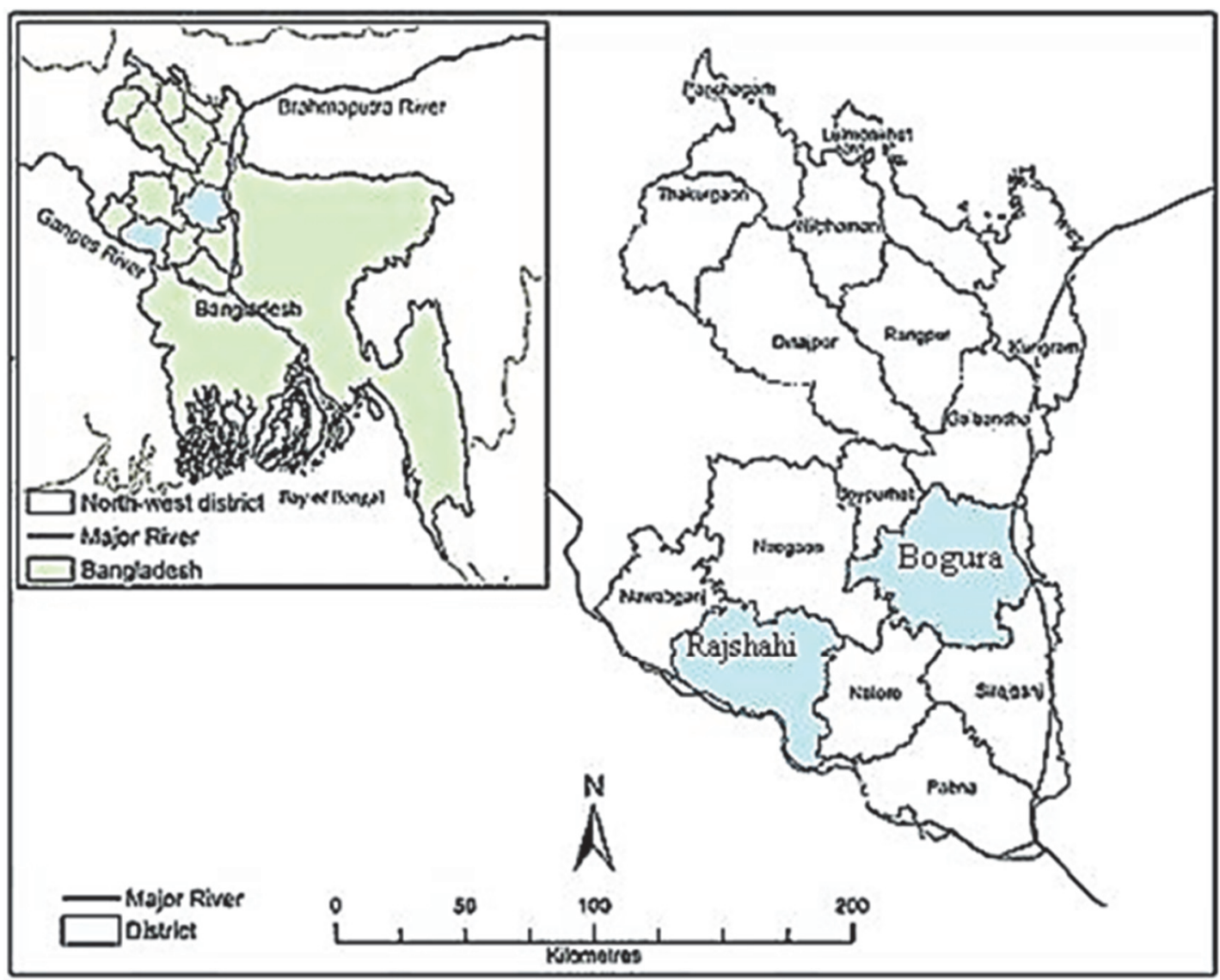

Figure 1. Locations Bogura and Rajshahi districts in Bangladesh

\subsection{Data Collection}

Data on daily reference crop evapotranspiration $\left(\mathrm{ET}_{\mathrm{o}}\right)$ and rainfall for the period 1985-2013 were collected from an on-going project (SDIP II: Sustaining groundwater irrigation for food security in the North-West region of Bangladesh) of CSIRO, Australia. The average, maximum and minimum $\mathrm{ET}_{\mathrm{o}}$ and rainfall for Bogura and Rajshahi districts are provided in Table A1 in Appendix. Data on crops such as length of growth stage, crop co-efficient, root depths, depletion factors, yield reduction factors, maximum ponding depth, minimum ponding depth, refill ponding depth, planting date and planting duration were collected from sub-district (called upazila) and district Agricultural Offices through SDIP II project. Planting date, length of growth stage and harvesting date of the crops for Bogura and Rajshahi districts are provided in Table A2 in Appendix. Out of a large number of cropping patterns (172 177) only six commonly practiced cropping patterns: aus-aman-boro, aus-aman-potato, aman-potato, vegetables-aman, mustard-aman and aus-fallow-wheat were investigated in this study, specifically to generate the basic information. It is noted that the cropping patterns in Bogura and Rajshahi districts have been changing over the years depending on many factors, such as irrigation facility, market price of the produce, profitability of the crop, food habit of the people, etc. We evaluated trend of water requirements of the crops and cropping patterns 
over the period from 1985 to 2013. Therefore, in selecting the crops and cropping patterns, we emphasized on cropping practices over this period. However, for complete scenario development for water use, all the crops and cropping patterns need to be investigated, which was not within the scope of this study. Data on soil-types, initial soil-moisture content, soil-moisture content at saturation and field capacity, residual soil-moisture content, saturated hydraulic conductivity and percolation rate for rice fields used in estimating water requirements are given in Table A3 in Appendix. The rooting depths, depletion factors, yield reduction factors and ponding depths of different crops used in the estimation are given in Table A4 in Appendix.

\subsection{Water Requirement Estimation}

Irrigation-water requirement was estimated by using Soil-Water Balance via CropWat (SWBcropwat) model of Mainuddin et al. (2014), which is a macro in MS excel sheets. This model calculates irrigation water requirement of crops and soil-water balance following the principle in Allen et al. (1998). For calculation of effective rainfall, the model utilized the method of USDA Soil Conservation Service (1993) that was developed based on long-term climatic and soil moisture data. It can perform calculation for one or more weather/climate sequences, crops and soils. The model can therefore calculate irrigation requirements and soil-water balance of many places within large areas and places with different climates, soils and crops. It was designed to do the calculations necessary for spatial assessments of irrigation requirements and soil-water balance. However, there is no any available sophisticated method to calculate infiltration and drainage for determining soil-water balance. But there is a simple and sophisticated option, called water content-dependent leaking buckets, in SWBcropwat. In this option, soil-water content is calculated daily by adding irrigation and rainfall, and subtracting evapotranspiration/soil evaporation, runoff and drainage. Whenever soil-water content exceeds saturation, the excess water is subtracted and added to runoff. Drainage is calculated from the water content-dependent hydraulic conductivity. Rice crop is treated differently with a fixed leakage rate, presumed to be lower than upland crop, because of puddling during the rice transplanting period. For water balance calculation, a working worksheet keeps link with input worksheets for rain, reference evapotranspiration, soil and crop data, multi-cropping sequence and irrigation-rules. The calculations are done in a macro, and the number of irrigations, total irrigation, total rain, crop-available rain, reference evapotranspiration, crop evapotranspiration, total drainage, total runoff, yield potential, etc. are generated as outputs to other worksheets. The water-balance outputs can be either annual or daily as desired by the user. For details on SWB model, the readers are referred to Mainuddin et al. (2014).

Crop evapotranspiration $\left(\mathrm{ET}_{\mathrm{c}}\right)$ was calculated by crop co-efficient approach in which $\mathrm{ET}_{\mathrm{c}}(\mathrm{mm} /$ day $)$ was calculated by multiplying reference evapotranspiration, $\mathrm{ET}_{\mathrm{o}}\left(\mathrm{mm} /\right.$ day), with crop co-efficient $\left(\mathrm{K}_{\mathrm{c}}\right.$, dimensionless) as

$$
E T_{\mathrm{c}}=K_{\mathrm{c}} \times E T_{\mathrm{o}}
$$

$\mathrm{ET}_{\mathrm{o}}$ being a climatic parameter expresses evaporative power of the atmosphere and is defined as the evapotranspiration from excellently managed, large, well-watered fields that achieve full production under the given climatic conditions. Differences in leaf anatomy, stomatal characteristics, aerodynamic properties and albedo cause $\mathrm{ET}_{\mathrm{c}}$ to differ from $\mathrm{ET}_{\mathrm{o}}$ under the same climatic conditions. Due to variations in the crop characteristics throughout the growing season, $\mathrm{K}_{\mathrm{c}}$ for a given crop changes from sowing till harvest. Its value for rice is generally greater than 1, especially during the vigorous growth period, but for other crops, it is less than 1 . We calculated effective rainfall by using the method of USDA Soil Conservation Service (1993) that was developed based on long-term climatic and soil moisture data.

\subsection{Trend Analysis}

The trend of monthly total rainfall and crop evapotranspiration $\left(\mathrm{ET}_{\mathrm{c}}\right)$; seasonal total $\mathrm{ET}_{\mathfrak{c}}$, effective rainfall (ER) and irrigation requirement (IR) of eight major crops; and $\mathrm{ET}_{\mathfrak{c}}, \mathrm{ER}$ and IR of six major cropping patterns were determined by using Mann-Kendall-Sens (MAKESENS) trend statistics (Salmi, 2002). An MS excel template for implementation of the MAKESENS model, developed for detecting and estimating trend in time series of annual values of atmospheric chemistry, are freely available as open source. The used statistical methods are the nonparametric Mann-Kendall test for analyzing the presence of monotonic increasing or decreasing trend and the nonparametric Sen's method for estimating the slope of a linear trend (Salmi, 2002). MAKESENS utilizes two statistics, called S-statistics and Z-statistics (Gilbert, 1987), to estimate trend. For time series with less than 10 data points, S-statistics is used, and for time series with $\geq 10$ data points, Z-statistics is used. If $x_{1}, x_{2}, x_{3}, \ldots, x_{\mathrm{j}}$ represent $n$ data points, where $x_{\mathrm{j}}$ is the data point at time $j$, Mann-Kendall statistics " $\mathrm{S}$ " is expressed by 


$$
S=\sum_{k=1}^{n-1} \sum_{j=k+1}^{n} \operatorname{sgn}\left(x_{j}-x_{k}\right)
$$

In Equation (1), $\operatorname{sgn}\left(x_{\mathrm{j}}-x_{\mathrm{k}}\right)=1$ for $x_{\mathrm{j}}-x_{\mathrm{k}}>0$, or $\operatorname{sgn}\left(x_{\mathrm{j}}-x_{\mathrm{k}}\right)=0$ for $x_{\mathrm{j}}-x_{\mathrm{k}}=0$, or $\operatorname{sgn}\left(x_{\mathrm{j}}-x_{\mathrm{k}}\right)=-1$ for $x_{\mathrm{j}}-x_{\mathrm{k}}<$ 0 . The normalized $Z$-statistics is given by

$$
\begin{array}{lr}
Z=\frac{S-1}{[\operatorname{VAR}(S)]^{1 / 2}} \quad \text { if } \mathrm{S}>0 \\
Z=\frac{S+1}{[\operatorname{VAR}(S)]^{1 / 2}} & \text { if } \mathrm{S}<0 \\
\mathrm{Z}=0 & \text { if } \mathrm{S}=0
\end{array}
$$

The MAKESENS model provides trends of the monthly total rainfall and $\mathrm{ET}_{\mathrm{c}}$; seasonal total $\mathrm{ET}_{\mathrm{c}}, \mathrm{ER}$ and IR of eight major crops; and $\mathrm{ET}_{\mathfrak{c}}, \mathrm{ER}$ and IR of six major cropping patterns in terms of Z-statistics (Equation (3)), slope, and intercept of the trend line. It also provides statistical significance of the observed trends in the values of the parameters. The Z-statistics is a deterministic index of the trend. The intercept and slope together provide the trend lines. The slope of the trend lines determines magnitude and direction of the trend. Based on data type, especially sensitivity of change, the MAKESENS model determines statistical significance of the trend at $p \leq 0.10, \leq 0.05$, $\leq 0.01$ and $\leq 0.001$. The Mann-Kendall test requires at least four values, and calculation of the confidence intervals for the Sen's slope estimate requires at least ten values in a time series.

\section{Results}

\subsection{Monthly Total Rainfall and Crop Evapotranspiration}

Negative values of Mann-Kendall trend statistics, Z (Table 1), revealed declining trend of monthly total rainfall in eight of the twelve months over the period 1985-2013 both in Bogura and Rajshahi districts, with the significant $(\mathrm{p} \leq 0.05)$ declining trend $(-8.67 \mathrm{~mm} / \mathrm{month} / \mathrm{year})$ in July. Monthly total rainfall increased slightly over the years in April, August and October in Bogura, and August and October in Rajshahi. Rainfall effectively remained invariant during January, March and December in both districts. The rate of variation (decreasing/increasing) of the monthly total rainfall was higher in Bogura than in Rajshahi district in most of the months. Monthly total crop evapotranspiration, $\mathrm{ET}_{\mathrm{c}}$ (Equation 1), declined significantly from October to April in Bogura and October to May

\begin{tabular}{|c|c|c|c|c|c|c|c|c|}
\hline \multirow[t]{3}{*}{ Months } & \multicolumn{4}{|c|}{ Rainfall } & \multicolumn{4}{|c|}{ Crop evapotranspiration, $\mathrm{ET}_{\mathrm{c}}$} \\
\hline & \multicolumn{2}{|c|}{ Bogura } & \multicolumn{2}{|c|}{ Rajshahi } & \multicolumn{2}{|c|}{ Bogura } & \multicolumn{2}{|c|}{ Rajshahi } \\
\hline & $\mathrm{Z}$ & $\mathrm{S}$ & $\mathrm{Z}$ & $\mathrm{S}$ & $\mathrm{Z}$ & $\mathrm{S}$ & $\mathrm{Z}$ & $\mathrm{S}$ \\
\hline January & 0.30 & 0.000 & 0.10 & 0.00 & $-5.08 * * *$ & -0.846 & $-4.26 * * *$ & -0.021 \\
\hline February & $-1.77+$ & -0.229 & $-1.78+$ & -0.33 & $-2.68 * *$ & -0.466 & $-2.53 *$ & -0.018 \\
\hline March & -0.06 & 0.000 & 0.06 & 0.00 & $-3.47 * * *$ & -0.951 & $-2.91 * *$ & -0.026 \\
\hline April & 0.32 & 0.433 & -0.49 & -0.54 & $-3.32 * * *$ & -0.892 & $-4.26 * * *$ & -0.047 \\
\hline May & $-1.76+$ & -3.211 & -0.08 & -0.09 & -0.88 & -0.356 & $-2.61 * *$ & -0.020 \\
\hline June & -1.54 & -4.604 & -0.09 & -0.53 & $-1.78+$ & -0.342 & -1.48 & -0.010 \\
\hline July & $-2.34 *$ & -8.667 & -1.18 & -4.21 & 1.29 & 0.367 & $1.67+$ & 0.010 \\
\hline August & 1.16 & 3.087 & 0.28 & 0.35 & -0.43 & -0.113 & -0.96 & -0.007 \\
\hline September & $-1.69+$ & -5.639 & -0.96 & -3.15 & 0.39 & 0.148 & 1.11 & 0.007 \\
\hline October & 0.17 & 1.022 & 0.41 & 0.58 & $-2.08 *$ & -0.346 & $-2.23 *$ & -0.011 \\
\hline November & -0.90 & 0.000 & -1.48 & -0.12 & $-3.43 * * *$ & -0.512 & $-2.61 * *$ & -0.010 \\
\hline December & $-1.69+$ & 0.000 & -1.56 & 0.00 & $-3.81 * * *$ & -0.799 & $-3.25 * *$ & -0.016 \\
\hline
\end{tabular}
in Rajshahi (Table 1). $\mathrm{ET}_{\mathrm{c}}$ showed slightly increasing trend in July and September in both districts but remained effectively unchanged in August and September in Rajshahi. Sen's slope revealed the higher declining rates of $\mathrm{ET}_{\mathrm{c}}$ in Bogura than in Rajshahi.

Table 1. Mann-Kendall trend values (Z; Equation 3) and Sen's slopes (S, mm/month/year; Equation 2) of monthly total rainfall and crop evapotranspiration $\left(\mathrm{ET}_{\mathrm{c}}\right)$ in Bogura and Rajshahi districts 


\subsection{Effective Rainfall and Crop-water Requirements}

Effective rainfall, ER, was always much less than crop evapotranspiration, $\mathrm{ET}_{\mathfrak{c}}$, for boro rice both in Bogura and Rajshahi districts (Fig. 2). $\mathrm{ET}_{\mathrm{c}}$ showed a gradual decreasing trend over the years of study. Large quantity of irrigation was needed for boro rice; the highest irrigation requirement was $588 \mathrm{~mm}$ in 1988-1989 and the lowest was $223 \mathrm{~mm}$ in 2001-2002 in Bogura. The corresponding quantity of irrigation requirement was $596 \mathrm{~mm}$ in 19881989 and $300 \mathrm{~mm}$ in 1999-2000 in Rajshahi. In contrast, ER was higher than $\mathrm{ET}_{\mathrm{c}}$ in most of the years for aus rice and always higher than $\mathrm{ET}_{\mathrm{c}}$ for aman rice. Therefore, only occasional supplemental irrigation was needed for aus rice but no irrigation was needed for aman rice in both districts. As demonstrated in Fig. 2, ER fluctuated over a wide range from year to year; for example, it was $1185 \mathrm{~mm}$ in the aus season of 1988 but only $315 \mathrm{~mm}$ in the aus season of 2012 in Bogura. Because of higher $\mathrm{ET}_{\mathrm{c}}$ than ER, irrigation was a necessity for vegetables and mustard both in Bogura and Rajshahi districts (Fig. 3). $\mathrm{ET}_{\mathrm{c}}$ for sugarcane remained unchanged over the years. Sugarcane being a perennial year-round crop received enough rainfall during its main growth period and, therefore, it did not require irrigation. $\mathrm{ET}_{\mathrm{c}}$ of wheat and potato was higher than $\mathrm{ER}$ in both districts and large quantity of irrigation was needed for these crops (Fig. 3). $\mathrm{ET}_{\mathrm{c}}$ of these crops decreased gradually over the study period.

Mann-Kendall trends (Z-statistics) of $\mathrm{ET}_{\mathrm{c}}$ of the crops were significant $(\mathrm{p} \leq 0.05)$ except for aman rice and sugarcane in Bogura and for aman rice in Rajshahi (Table 2). Negative values of $Z$ revealed declining trend of $E_{c}$ except for aman rice and sugarcane for Bogura and aman for Rajshahi. The most declining trend was for boro rice $(4.37 \mathrm{~mm} / \mathrm{season} /$ year) in Bogura and sugarcane $(5.31 \mathrm{~mm} / \mathrm{season} / \mathrm{year})$ in Rajshahi. Although effective rainfall was declining, none of the Mann-Kendall value was significant for the crops under investigation. Sen's slopes showed declining rate of irrigation requirement, IR, except for aus, aman and sugarcane in both districts (Table 2). The declining trend of IR was significant for boro rice, potato and vegetables in Bogura and for mustard and vegetables in Rajshahi.
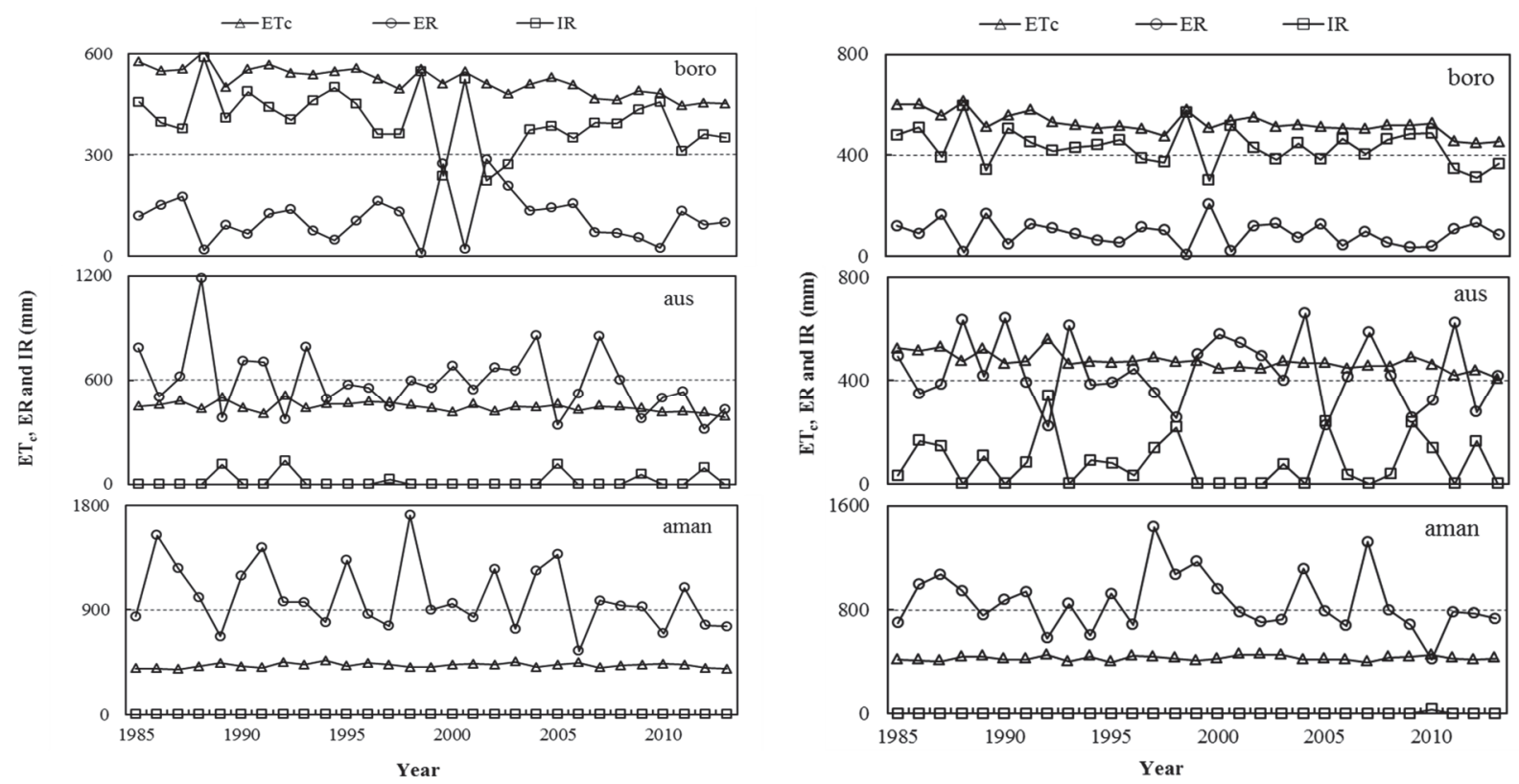

Figure 2. Variation of crop evapotranspiration $\left(\mathrm{ET}_{\mathrm{c}}\right)$, effective rainfall (ER) and irrigation requirement (IR) of boro, aus and aman rice during 1985-2013 in Bogura (left) and Rajshahi (right) districts 

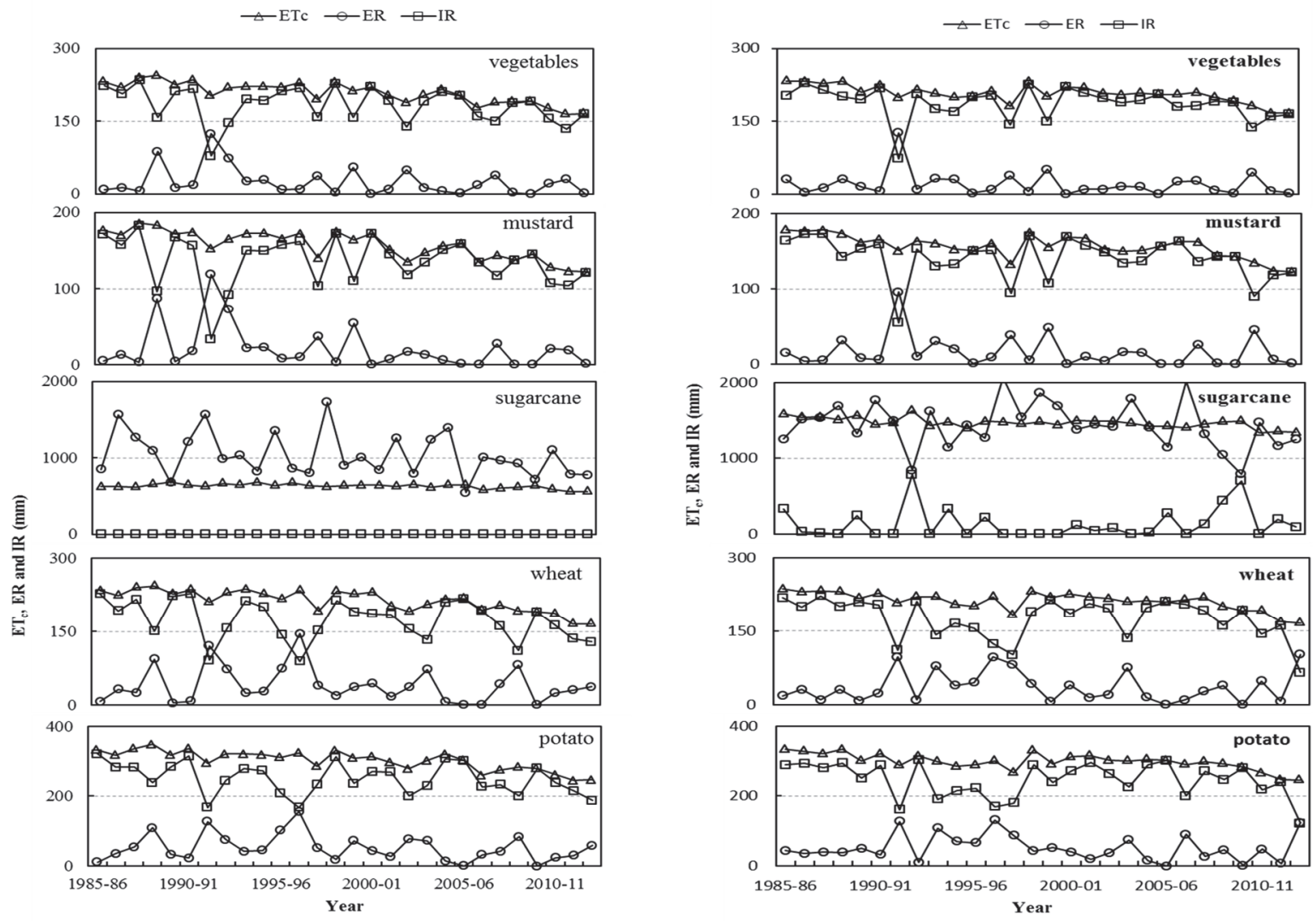

Figure 3. Variation of crop evapotranspiration $\left(\mathrm{ET}_{\mathrm{c}}\right)$, effective rainfall (ER) and irrigation requirement (IR) of vegetables, mustard, sugarcane, wheat and potato during 1985-2013 in Bogura (left) and Rajshahi (right) districts

Table 2. Mann-Kendall trend (Z; Equation 3) and Sen's slope (S, mm/season/year; Equation 2) of estimated crop evapotranspiration $\left(\mathrm{ET}_{\mathrm{c}}, \mathrm{mm} / \mathrm{season}\right)$, effective rainfall (ER, $\mathrm{mm} / \mathrm{season}$ ) and irrigation requirement (IR, $\mathrm{mm} /$ season) of eight major crops under study in Bogura and Rajshahi districts

\begin{tabular}{|c|c|c|c|c|c|c|c|c|c|c|c|c|}
\hline \multirow[t]{3}{*}{ Crops } & \multicolumn{6}{|c|}{ Bogura } & \multicolumn{6}{|c|}{ Rajshahi } \\
\hline & \multicolumn{2}{|c|}{$\mathrm{ET}_{\mathrm{c}}$} & \multicolumn{2}{|c|}{ ER } & \multicolumn{2}{|c|}{ IR } & \multicolumn{2}{|c|}{$\mathrm{ET}_{\mathrm{c}}$} & \multicolumn{2}{|c|}{ ER } & \multicolumn{2}{|c|}{ IR } \\
\hline & $\mathrm{Z}$ & $\mathrm{S}$ & Z & $\mathrm{S}$ & $\mathrm{Z}$ & $\mathrm{S}$ & Z & $\mathrm{S}$ & $Z$ & $\mathrm{~S}$ & $\mathrm{Z}$ & $\mathrm{S}$ \\
\hline Boro & $-4.96 * * *$ & -4.37 & -0.30 & -0.65 & $-2.03 *$ & -3.13 & $-3.50 * * *$ & -3.71 & -0.75 & -1.02 & -1.36 & -2.56 \\
\hline Aus & $-2.76^{* *}$ & -1.85 & $-1.74+$ & -5.48 & 0.43 & 0.00 & $-4.03 * * *$ & -2.59 & -0.17 & -0.69 & -0.54 & 0.00 \\
\hline Aman & 0.73 & 0.16 & -1.74 & -9.96 & 0.00 & 0.00 & 0.73 & 0.16 & $-1.74+$ & -9.95 & 0.00 & 0.00 \\
\hline Mustard & $-4.76^{* * *}$ & -1.88 & $-1.70+$ & -0.39 & $-1.68+$ & -1.23 & $-3.93 * * *$ & -1.35 & -1.21 & -0.26 & $-2.07 *$ & -0.95 \\
\hline Potato & $-4.48 * * *$ & -2.79 & -0.97 & -0.71 & $-2.23 *$ & -1.80 & $-3.54 * * *$ & -1.89 & -0.79 & -0.77 & -1.09 & -1.17 \\
\hline Vegetables & $-4.72 * * *$ & -2.21 & -1.25 & -0.46 & $-2.19 *$ & -1.52 & $-3.81 * * *$ & -1.50 & -1.03 & -0.25 & $-2.35^{*}$ & -1.25 \\
\hline Sugarcane & -2.68 & -2.00 & -1.80 & -10.71 & 0.00 & 0.00 & $-3.28 * *$ & -5.31 & -1.29 & -8.68 & 0.68 & 0.00 \\
\hline Wheat & $-4.52 * * *$ & -2.15 & -0.59 & -0.28 & $-1.96+$ & -1.85 & $-4.29 * * *$ & -1.39 & -0.24 & -0.14 & $-1.80+$ & -1.19 \\
\hline
\end{tabular}

\subsection{Water Requirements of Major Cropping Patterns}

The effective rainfall was less than $\mathrm{ET}_{\mathrm{c}}$ for the cropping patterns over the study period (1985-2013), and hence irrigation was needed for aus-aman-boro, aus-aman-potato, aman-potato-fallow, vegetables-aman, amanmustard-fallow and aus-fallow-wheat patterns both in Bogura and Rajshahi districts (Figs. 4 and 5). In spite of some inter-annual fluctuations, $\mathrm{ET}_{\mathrm{c}}$ for the cropping patterns decreased gradually over the years. But, because of larger inter-annual fluctuation in the effective rainfall, irrigation requirement for the cropping patterns also fluctuated in parallel to the effective rainfall. 

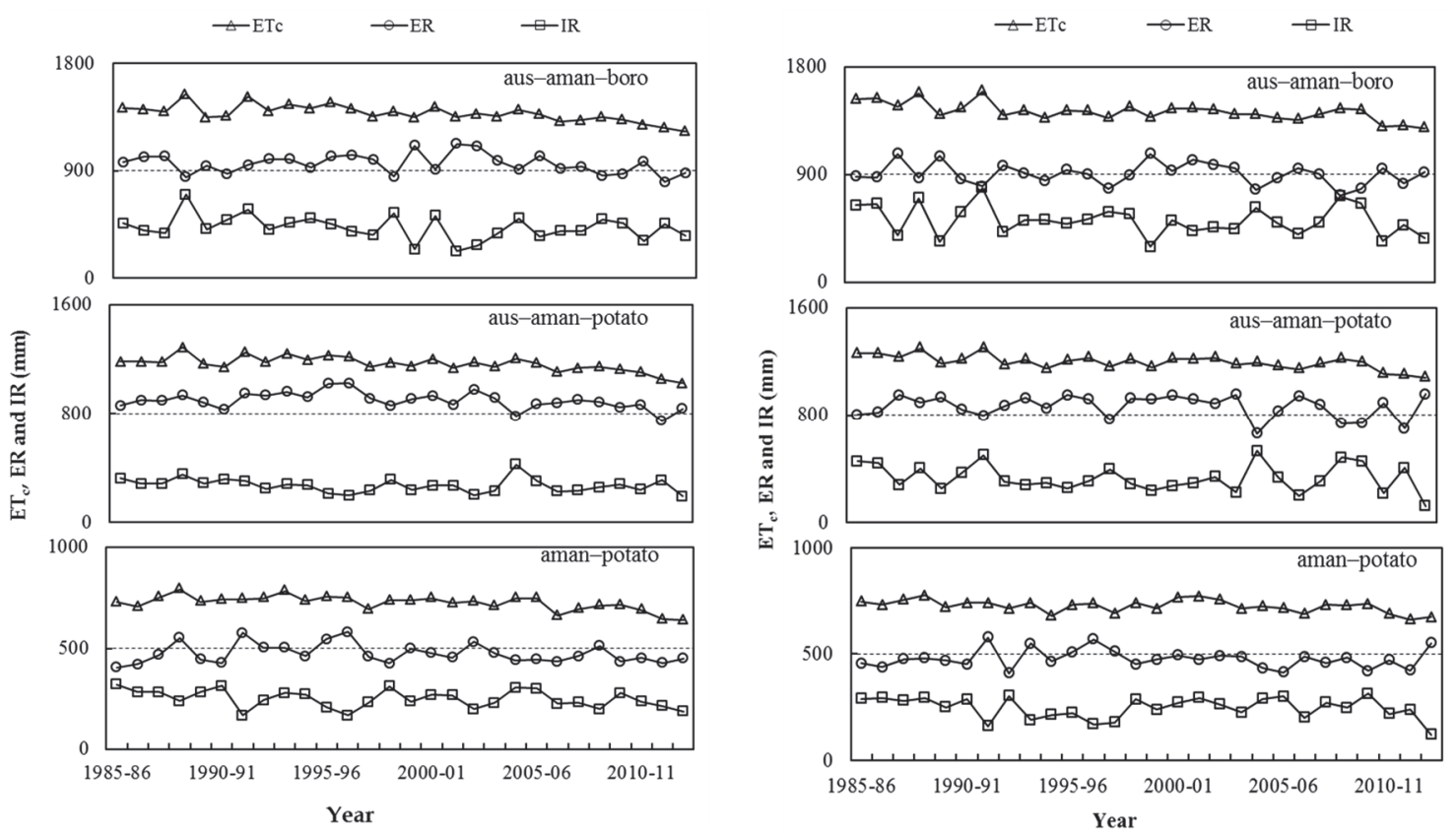

Figure 4. Variation of crop evapotranspiration $\left(\mathrm{ET}_{\mathrm{c}}\right)$, effective rainfall (ER) and irrigation requirement (IR) of aus-aman-boro, aus-aman-potato and aman-potato cropping patterns during 1985-2013 in Bogura (left) and

Rajshahi (right) districts
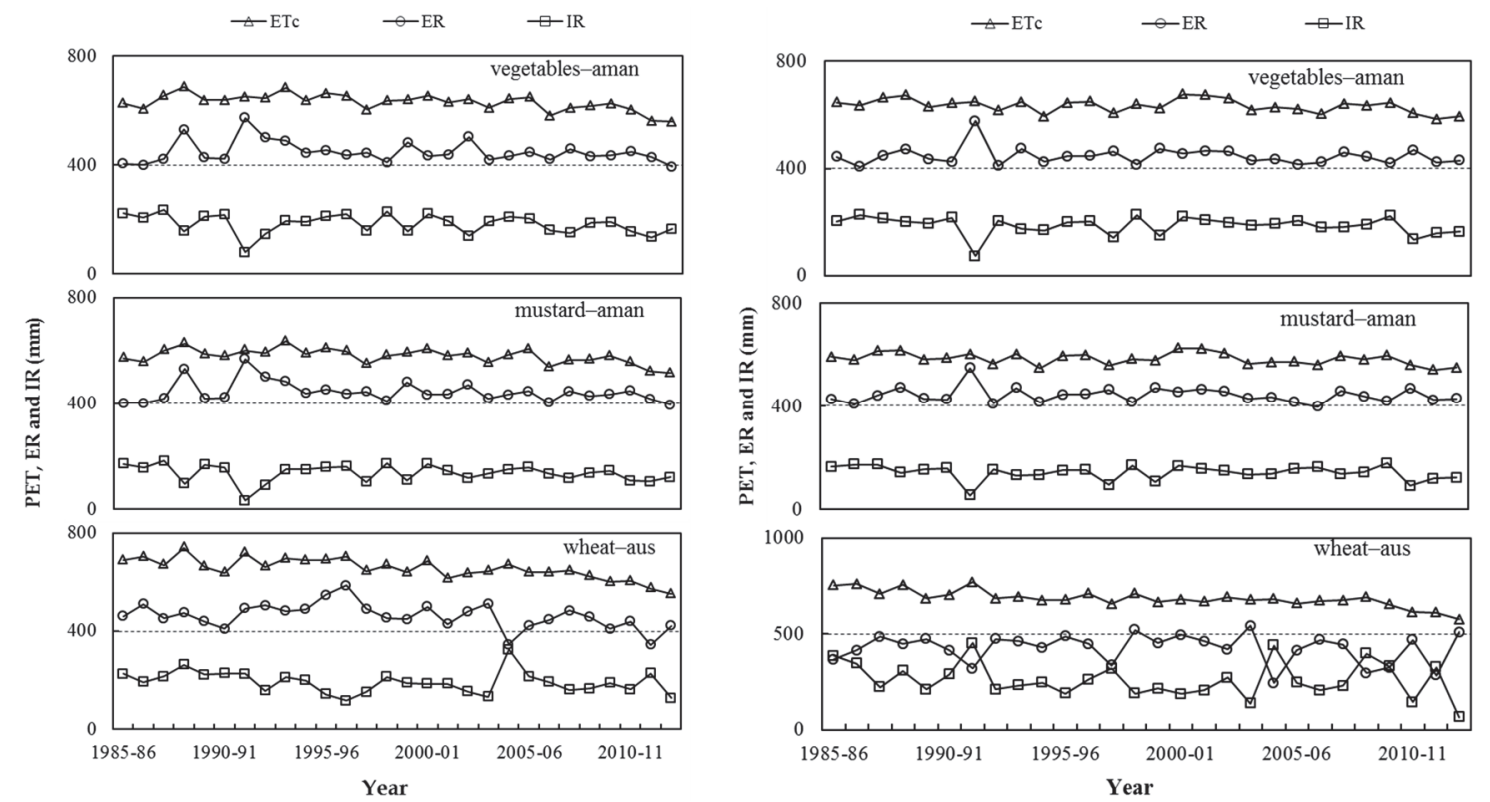

Figure 5. Variation of crop evapotranspiration $\left(\mathrm{ET}_{\mathrm{c}}\right)$, effective rainfall (ER) and irrigation requirement (IR) of vegetables-aman, mustard-aman and wheat-aus cropping patterns during 1985-2013 in Bogura (left) and Rajshahi (right) districts

The Mann-Kendall Z-value for $\mathrm{ET}_{\mathrm{c}}$ showed significant decreasing trend for the cropping patterns except for amanmustard-fallow pattern in Rajshahi (Table 3). The most declining rate of $\mathrm{ET}_{\mathrm{c}}$ was for aus-aman-boro pattern in both districts, with Sen's slope of -6.30 ( $\mathrm{mm} /$ year) for Bogura and $-5.75(\mathrm{~mm} /$ year) for Rajshahi that represented declining rates of $\mathrm{ET}_{\mathrm{c}}$. The effective rainfall for the cropping patterns remained effectively unchanged. Irrigation requirement for the cropping patterns declined over the years, with significant declining trend for aus-aman-potato, aman-potato-fallow and vegetables-aman patterns in Bogura. 
Table 3. Mann-Kendall trend (Z-statistics; Equation 3) and Sen's slope (S, mm/season/year; Equation 2) of crop evapotranspiration $\left(\mathrm{ET}_{\mathrm{c}}, \mathrm{mm} / \mathrm{season}\right)$, effective rainfall (ER, $\mathrm{mm} / \mathrm{season}$ ) and irrigation requirement (IR, $\mathrm{mm} /$ season) of six major cropping patterns in Bogura and Rajshahi districts

\begin{tabular}{|c|c|c|c|c|c|c|c|c|c|c|c|c|}
\hline \multirow{3}{*}{ Cropping patterns } & \multicolumn{6}{|c|}{ Bogura } & \multicolumn{6}{|c|}{ Rajshahi } \\
\hline & \multicolumn{2}{|c|}{$\mathrm{ET}_{\mathrm{c}}$} & \multicolumn{2}{|c|}{ ER } & \multicolumn{2}{|c|}{ IR } & \multicolumn{2}{|c|}{$\mathrm{ET}_{\mathrm{c}}$} & \multicolumn{2}{|c|}{ ER } & \multicolumn{2}{|c|}{ IR } \\
\hline & $\mathrm{Z}$ & $\mathrm{S}$ & $\mathrm{Z}$ & $\mathrm{S}$ & $\mathrm{Z}$ & $\mathrm{S}$ & $\mathrm{Z}$ & $\mathrm{S}$ & $\mathrm{Z}$ & $\mathrm{S}$ & $\mathrm{Z}$ & S \\
\hline Aus-aman-boro & $-4.01 * * *$ & -6.30 & -1.17 & -2.46 & -1.52 & -2.88 & $-3.34 * * *$ & -5.75 & -0.81 & -2.05 & -1.28 & -5.22 \\
\hline Aus-aman-potato & $-3.89 * * *$ & -4.96 & $-1.96+$ & -2.68 & $-2.11^{*}$ & -1.77 & $-3.30 * * *$ & -4.00 & -0.30 & -0.66 & -1.01 & -3.47 \\
\hline Aman-potato-fallow & $-2.86 * *$ & -2.59 & -0.73 & -0.87 & $-2.23 *$ & -1.80 & $-2.39 *$ & -1.50 & -0.38 & -0.41 & -0.69 & -1.06 \\
\hline Vegetables-aman & $-2.83 * *$ & -2.13 & -0.45 & -0.39 & $-2.19 *$ & -1.52 & $-2.27^{*}$ & -1.50 & -0.49 & -0.22 & $-1.80+$ & -1.12 \\
\hline Aman-mustard-fallow & $-2.55^{*}$ & -1.81 & -0.73 & -0.50 & $-1.68+$ & -1.23 & $-1.96+$ & -1.18 & -0.18 & -0.14 & -1.48 & -0.86 \\
\hline Aus-fallow-wheat & $-4.37 * * *$ & -4.67 & -1.56 & -2.01 & $-1.68+$ & -1.95 & $-4.37 * * *$ & -4.27 & -0.30 & -0.28 & -0.93 & -2.03 \\
\hline
\end{tabular}

$+, *, * *$ and $* * *$ signs indicate significant at $\mathrm{p} \leq 0.10, \leq 0.05, \leq 0.01$ and $\leq 0.001$ level of significance, respectively.

\subsection{Crop Evapotranspiration as Influenced by Changing Cropping Area}

The seasonal total volume of crop evapotranspiration, $\mathrm{ET}_{\mathrm{c}}$, of boro rice increased gradually from 1985 to 2005 in Bogura and from 1985 to 2010 in Rajshahi district and then decreased in both districts (Fig. 6) in response to a similar change in cropping area of boro rice. It is noted that data on cropping area for boro, aus and aman were not available for the period 2001-2007 and also similar data for potato were not available for the period 2005-2010 for Rajshahi. $\mathrm{ET}_{\mathrm{c}}$ of aus rice decreased up to the year 2005, after which it increased to some extent. $\mathrm{ET}_{\mathrm{c}} \mathrm{of}$ the aman rice remained unchanged except slight inter-annual variations in both the districts. In Bogura, ET $\mathrm{c}_{\mathrm{c}}$ of wheat decreased but that of potato increased, with rapid change in $\mathrm{ET}_{\mathrm{c}}$ from the year 2000. In Rajshahi, $\mathrm{ET}_{\mathrm{c}}$ for wheat and potato remained unchanged from 1985 to 1998 and then increased. There was a direct positive correlation with $\mathrm{ET}_{\mathrm{c}}$ and cropping area in both districts that clearly indicated an adjustment in the cropping patterns by choosing crops, plausibly mainly based on availability of irrigation water among other factors.

\section{Discussion}

\subsection{Under-utilized Effective Rainfall}

The effective rainfall, ER, was substantially larger than crop evapotranspiration, $\mathrm{ET}_{\mathrm{c}}$, of aus rice in Bogura district (Fig. 2). Therefore, no irrigation was needed and a part of ER remained unutilized. In Rajshahi district, on the other hand, ER was considerably larger than $\mathrm{ET}_{\mathrm{c}}$ of aus rice in some years and considerably smaller than $\mathrm{ET}_{\mathrm{c}}$ in other years (Fig. 2), revealing the necessity of supplemental irrigation when ER was effectively smaller than ET of the crop in Rajshahi. For aman rice, ER being about double the amount of $\mathrm{ET}_{\mathrm{c}}$ indicated no requirement of irrigation (Fig. 2) and unutilized ER. By estimating water requirement for aman rice for 2005-2012 seasons in Tanore upazila of Rajshahi district, Hasan et al. (2019) also showed no irrigation requirement for this crop during June to September due to high rainfall. For sugarcane cultivation, ER was significantly greater than $\mathrm{ET}_{\mathrm{c}}$ in Bogura but mostly equal to $\mathrm{ET}_{\mathrm{c}}$ in Rajshahi (Fig. 3). Although ERs during some crop-growing periods were larger than the crops' seasonal total $\mathrm{ET}_{\mathrm{c}}$, they were always significantly smaller than $\mathrm{ET}_{\mathrm{c}}$ for the six cropping patterns under investigation (Figs. 4 and 5). The reason for this was that the excess ER for a crop period could not be transferred to the next season for another crop in the pattern; the excess ER was always wasted. The effective rainfall, ER, was estimated from the daily total rainfall based on soil-water retention capacity for the upland crops and allowable standing water depths for irrigated rice crops. The two districts under study are drought-prone (Hussain, 2017); often there were long rainless dry periods (32-48 days) depending on duration of the droughts (BanDuDeltAS, 2015; Mojid, 2020). This means that the rainfall events were not uniformly distributed over the crop periods, and hence potential ER from the rainfalls could not be utilized fully. The large rainfall events might exceed soil's retention capacity and standing water depths in the rice fields and the excess amounts were lost through surface runoff and deep percolation. Therefore, there remain ample scopes for rainwater harvesting in both districts (Masum et al., 2013) that can be utilized for irrigation in the following dry season crop cultivation. 

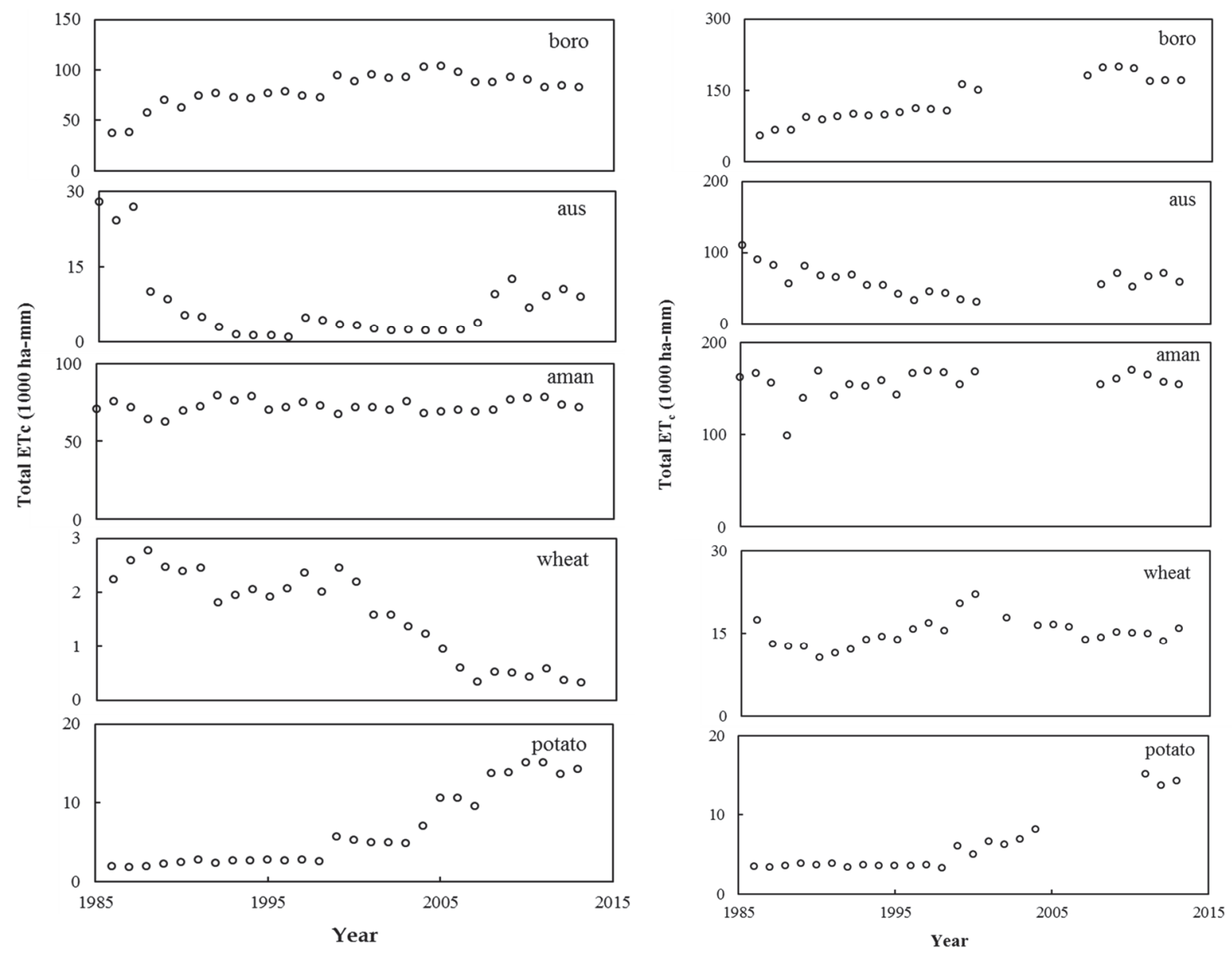

Figure 6. Changes in total volume of crop evapotranspiration $\left(\mathrm{ET}_{\mathrm{c}}\right)$ of boro rice, aus rice, aman rice, wheat and potato due to changes in cropping area during 1984/1985 to 2012/2013 in Bogura (left) and Rajshahi (right) districts

\subsection{Cropping Pattern Selection}

Selection of a cropping pattern is governed by several factors such as crop suitability to local conditions, local food habits, economic profitability of the produce and availability of inputs for production of the crops, among which irrigation water availability is the most crucial one for the study areas. Both in Bogura and Rajshahi districts, irrigation areas expanded significantly (BBS, 2017) over the study period (1985-2013) due to increasing food production, especially boro rice production, to meet increasing food demand. However, due to scanty and uncertain rainfall in the dry season (October-April), boro rice cultivation is fully dependent on irrigation (Masum et al., 2013). This has already caused scarcity of irrigation water for dry season crop production. The amount of rainfall in the North-West region of Bangladesh, within which the study areas are located, is progressively declining. The average annual rainfall (1985-2015) of six major rain gauge stations in this region shows a declining trend of 9.2 $\mathrm{mm} /$ year (Mojid et al., 2019). The water-scarcity situations in the study areas are expected to be much worse in future since irrigation water requirement can increase by $1 \%$ to $5 \%$ in 2050 depending on crop selection (Mainuddin et al., 2015). Although rice crop itself will not require extra amount of water for its conjunctive use (Kader et al., 2014; Mojid et al., 2015) the increasing irrigation command area and warmer climate will require more water to be pumped (Shahid, 2011). This will ultimately aggravate the already stressed groundwater resources of the study areas. Due to scarcity of irrigation water during the dry season crop production, many farmers in the study areas have been already compelled to shift from high-water demanding boro rice to low-water demanding crops like potato, wheat, vegetables, fruit, etc. Such dynamism in crop selection is guided by significant differences in the quantities of irrigation requirement for different cropping patterns (Figs. 4 and 5). Consequently, appropriate planning of agriculture by selecting the proper cropping pattern(s) based on available water for irrigation shall remain a major policy option for the future to continue agricultural production in the study areas. 
However, shifting the cropping patterns will also have some limitations because of food habits and custom of the local people. Along with crop selection, serious efforts to increase water availability for irrigation may be needed. In this regard, the excess rainwater, currently returned as surface runoff, will be an important water source to be harvested in ponds and reservoirs for using in dry season irrigation in the future. Another option will be adoption of techniques for induced natural recharge and artificial recharge to groundwater aquifers during the wet season.

\section{Conclusions}

Monthly total rainfall and seasonal effective rainfall for the major crops and cropping patterns decreased gradually in Bogura and Rajshahi districts over the years 1985-2013 except in January, August and October. Whatever effective rainfalls occurred might not be utilized fully because of their non-uniform temporal distributions. So, the dry season crop period (November-April) became drier over this period. To the wonder, irrigation requirement of the widely practiced cropping patterns also revealed declining trend due to decrease in crop evapotranspiration, $\mathrm{ET}_{\mathrm{c}}$, of the crops. In response to increasing boro rice area, its seasonal total $\mathrm{ET}_{\mathrm{c}}$ increased gradually up to 2005 in Bogura and 2010 in Rajshahi. This caused scarcity of irrigation water and forced the farmers to shift from the high water-demanding boro rice to low water-demanding wheat and potato cultivation. Irrigation requirement of the cropping patterns was in the order: aus-aman-boro $>$ aus-aman-potato $>$ aman-potato $>$ wheat-aus $>$ vegetablesaman $>$ mustard-aman for Bogura, and aus-aman-boro $>$ aus-aman-potato $>$ wheat-aus $>$ aman-potato $>$ vegetablesaman $>$ mustard-aman for Rajshahi. Due to the decreasing trends of effective rainfall and dynamic shift in cropchoice by the farmers in response to increasing irrigation area, continuous adjustment of irrigation-based crop planning is necessary for optimum production by resource optimization. The methodology and findings of this study can be used for periodic evaluation of crop suitability and cropping patterns based on available water resources in the study areas. This study estimated water requirements of some selected crops and cropping patterns only by SWBcropwat model. We suggest using other methods for these estimations in order to verify our results. Future research can focus on climate variability and change of the study areas and estimating water requirements of all crops and cropping patterns under changing climatic condition.

\section{Conflict of interest}

The authors declare that there is no conflict of interest.

\section{References}

Acharjee, T. K., Halsema, G. V., Ludwig, F., \& Hellegers, P. (2017a). Declining trends of water requirements of dry season boro rice in the North-West Bangladesh. Agricultural Water Management, 180, 148-159. https://doi: 10.1016/j.agwat.2016.11.014

Acharjee, T. K., Ludwig, F., Halsema, G, V., Hellegers, P., \& Supit, I. (2017b). Future changes in water requirements of boro rice in the face of climate change in North-West Bangladesh. Agricultural Water Management, 194, 172-183. https://doi.org/10.1016/j.agwat.2017.09.008

Ahmad, M. U. D., Kirby, J. M., Islam, M. S., Hossain, M. J., \& Islam, M. M. (2014). Groundwater use for irrigation and its productivity: status and opportunities for crop intensification for food security in Bangladesh. Water Resources Management, 28, 1415-1429. https://doi.org/10.1007/s11269-014-0560-z

Allen, R. G., Pereira, L. S., Raes, D., \& Smith, M. (1998). Crop Evapotranspiration: Guidelines for Computing Crop Water Requirements. FAO Irrigation and Drainage Paper 56. Food and Agriculture Organization, Rome. pp. 1-15.

BanDuDeltAS. (2015). Baseline Report on Climate Change. Dhaka: Bangladesh Delta Plan 2100 Formulation Project. Bangladesh Planning Commission, Government of the People's Republic of Bangladesh, Dhaka, Bangladesh.

BBS (Bangladesh Bureau of Statistics). (2014). Bangladesh Population and Housing Census 2011, Community Report, Zila: Bogura. Statistics and Informatics Division (SID), Ministry of Planning, Government of the People's Republic of Bangladesh, Dhaka.

BBS (Bangladesh Bureau of Statistics). (2017). Yearbook 16, Series 28. Statistics and Informatics Division (SID), Ministry of Planning, Government of the People's Republic of Bangladesh, Dhaka.

BDP 2100 (Bangladesh Delta Plan 2100). (2017). Bangladesh Delta Plan 2100. Bangladesh Planning Commission, Government of the People's Republic of Bangladesh, Dhaka. Retrieved from http://www.lged.gov.bd/UploadedDocument/UnitPublication/17/624/Bangladesh\%20Delta\%20Plan\%20210 0\%20Draft\%20Report.pdf.

Bindraban, P. S. (2001). Water for Food: Converting Inundated Rice into Dry Rice. In: H Hengsdijk and PS 
Bindraban (Editors), Water-saving in Rice Production Systems at Nanjing University, China. Plant Research International (PRI), Report 33, Wageningen, Netherlands. pp. 5-14.

Brammer, H. (1987). Drought in Bangladesh: lessons for planners and administrators. Disasters, 11, 21-29. https://doi: 10.1111/j.1467-7717.1987.tb00611.x

CAWMA (Comprehensive Assessment of Water Management in Agriculture). (2007). Water for Food, Water for Life: A Comprehensive Assessment of Water Management in Agriculture. London: Earthscan, and Colombo: International Water Management Institute.

CSIRO, WARPO, BWDB, IWM, BIDS, \& CEGIS. (2014). Bangladesh Integrated Water Resources Assessment: Final Report. CSIRO, Australia, Available at: https://publications.csiro.au/rpr/download?pid=csiro:EP142841\&dsid=DS3 (accessed 5 May 2020).

Gilbert, R. O. (1987). Statistical Methods for Environmental Pollution Monitoring. John Wiley \& Sons: Manhattan, NY, USA.

Hasan, M. R., Nuruzzaman, M., \& Mamun, A. A. (2019). Contribution of rainwater to the irrigation requirement for paddy cultivation at Tanore Upazila in Rajshahi, Bangladesh. Air, Soil and Water Research, 12, p.1178622119837544. https://doi.org/10.1177/1178622119837544

Hasanuzzaman, M., Song, X., Han, D., Zhang, Y., \& Hussain, S. (2017). Prediction of groundwater dynamics for sustainable water resource management in Bogura district, Northwest Bangladesh. Water, 9, 1-17. https://doi.org/10.3390/w9040238

Hossain, M. B., Yesmin, S., Maniruzzaman, M., \& Biswas, J. C. (2017). Irrigation scheduling of rice (Oryza sativa L.) using CROPWAT model in the western region of Bangladesh. The Agriculturists, 15, 19-27. https://doi.org/10.3329/agric.v15i1.33425

Hussain, S. G. (2017). Identification and Modeling of Suitable Cropping Systems and Patterns for Saline, Drought and Flood Prone Areas of Bangladesh. Climate Change Unit, Christian Commission for Development in Bangladesh (CCDB). Dhaka, Bangladesh.

Islam, A. B. M. J., Shahidullah, S. M., Mostafizur, A. B. M., \& Saha, A. (2017). Diversity of cropping pattern in Bogra. Bangladesh Rice Journal, 21, 73-90. https://doi.org/10.3329/brj.v21i2.38197

Kader, M. A., Karim, N. N., \& Mojid, M. A. (2014). Impact of climate change on actual crop evapotranspiration of boro rice in Rajshahi division. Journal of Agricultural Engineering, 41, 23-30.

Kirby, J. M., Ahmad, M. D., Poulton, P., Zhu, Z., Lee, G., \& Mainuddin, M. (2013). Review of Water, Crop Production and System Modelling Approaches for Food Security Studies in the Eastern Gangetic Plains. CSIRO, Australia.

Kirby, J. M., Mainuddin, M., Mpelasoka, F., Ahmad, M. D., Palash, W., Quadir, M. E., Shah-Newaz, S. M. \& Hossain, M. M. (2016). The impact of climate change on regional water balances in Bangladesh. Climatic Change, 135, 481-491. https://doi.org/10.1007/s10584-016-1597-1

Mainuddin, M., \& Kirby, J. M. (2015). National food security in Bangladesh to 2050. Food Security, 7, 633-646. https://doi.org/10.1007/s12571-015-0465-6.

Mainuddin, M., Kirby, J. M., Chowdhury, R. A. R., Sanjida, L., Sarker, M. H., \& Shah- Newaz, S. M. (2014). Bangladesh Integrated Water Resources Assessment Supplementary Report: Land Use, Crop Production, and Irrigation Demand. CSIRO: Water for a Healthy Country Flagship, Australia.

Mainuddin, M., Kirby, M., Chowdhury, R. A. R., \& Shah-Newaz, S. M. (2015). Spatial and temporal variations of, and the impact of climate change on, the dry season crop irrigation requirements in Bangladesh. Irrigation Science, 33, 107-120. https://doi.org/10.1007/s00271-014-0451-3

Masum, A. A., Alam, M. Z., \& Chowdhury, A. (2013). Potential rainwater harvesting for irrigation in Godagari Upazila, Rajshahi. International Journal of Engineering Research and Applications, 3, 173-175. https://doi.org/10.1177/1178622119837544

Mojid, M. A. (2020). Climate change-induced challenges to sustainable development in Bangladesh. In IOP Conference Series: Earth and Environmental Science (Vol. 423, No. 1, p. 012001). IOP Publishing. https://doi.org/10.1088/1755-1315/423/1/012001

Mojid, M. A., Parvez, M. F., Mainuddin, M., \& Hodgson, G. (2019). Water table trend - a sustainability status of groundwater development in North-West Bangladesh. Water, 11, p.1182. https://doi.org/10.3390/w11061182 
Mojid, M. A., Rannu, R. P., \& Karim, N. N. (2015). Climate change impacts on reference crop evapotranspiration in North-West hydrological region of Bangladesh. International Journal of Climatology, 35, 4041-4046. https://doi.org/10.1002/joc. 4260

Peacock, T. (1996). Guidelines for Planning Irrigation and Drainage Investment Projects (Vol. 11). Food and Agriculture Organization of the UN (FAO).

Rashid, M. H. A., Islam, A. B. M. J., Shirazy, B. J., \& Shahidullah, S. M. (2017). Cropping systems and land use pattern in Rajshahi Region. Bangladesh Rice Journal, 21, 237-254. https://doi.org/10.3329/brj.v21i2.38209

Salmi, T. (2002). Detecting Trends of Annual Values of Atmospheric Pollutants by the Mann-Kendall Test and Sen's Slope Estimates-the Excel Template Application MAKESENS. Ilmatieteen Laitos: Helsinki, Finland.

Shahid, S. (2011). Impact of climate change on irrigation water demand of dry season Boro rice in northwest Bangladesh. Climate Change, 105, 433-453. https://doi.org/10.1007/s10584-010-9895-5

United Nations (UN). (2017). World Population Prospects: The 2017 Revision, Volume I-Comprehensive Tables. United Nations.

USDA Soil Conservation Service. (1993). Irrigation Water Requirements. National Engineering Handbook, Part 623, chapter 2, National Technical Information Service, United States Department of Agriculture.

Wikipedia. (2018). Rajshahi. https://en.wikipedia.org/wiki/Rajshahi_District (accessed 5 May 2020).

World Bank. (2015). Bangladesh - Climate change and sustainable development. Washington, DC: World Bank.

\section{Appendix}

Table A1. Monthly average, maximum and minimum reference crop evapotranspiration $\left(\mathrm{ET}_{0}\right)$ and rainfall in Bogura and Rajshashi districts

\begin{tabular}{|c|c|c|c|c|c|c|c|c|c|c|c|c|c|c|}
\hline \multirow[t]{2}{*}{ Districts } & \multicolumn{2}{|c|}{ Parameters } & \multicolumn{12}{|c|}{ Month } \\
\hline & & & Jan & Feb & Mar & Apr & May & Jun & Jul & Aug & Sep & Oct & Nov & Dec \\
\hline \multirow[t]{6}{*}{ Bogura } & \multirow{3}{*}{$\begin{array}{l}\mathrm{ET}_{\mathrm{o}} \\
(\mathrm{mm})\end{array}$} & Avg. & 69 & 91 & 134 & 144 & 145 & 122 & 118 & 119 & 107 & 106 & 84 & 68 \\
\hline & & Max. & 83 & 104 & 164 & 176 & 170 & 139 & 139 & 137 & 121 & 119 & 95 & 79 \\
\hline & & Min. & 50 & 73 & 110 & 123 & 105 & 102 & 94 & 102 & 89 & 88 & 69 & 44 \\
\hline & \multirow{3}{*}{$\begin{array}{l}\text { Rainfall } \\
(\mathrm{mm})\end{array}$} & Avg. & 7 & 12 & 18 & 77 & 195 & 322 & 356 & 296 & 300 & 156 & 12 & 7 \\
\hline & & Max. & 65 & 53 & 76 & 284 & 416 & 756 & 749 & 623 & 733 & 523 & 92 & 112 \\
\hline & & Min. & 0 & 0 & 0 & 0 & 92 & 128 & 92 & 111 & 99 & 0 & 0 & 0 \\
\hline \multirow[t]{6}{*}{ Rajshahi } & \multirow{3}{*}{$\begin{array}{l}\mathrm{ET}_{\mathrm{o}} \\
(\mathrm{mm})\end{array}$} & Avg. & 69 & 89 & 134 & 156 & 155 & 129 & 119 & 120 & 109 & 105 & 83 & 68 \\
\hline & & Max. & 81 & 105 & 174 & 197 & 176 & 154 & 135 & 138 & 124 & 118 & 90 & 78 \\
\hline & & Min. & 55 & 75 & 116 & 131 & 117 & 115 & 101 & 106 & 94 & 89 & 68 & 49 \\
\hline & \multirow{3}{*}{$\begin{array}{l}\text { Rainfall } \\
(\mathrm{mm})\end{array}$} & Avg. & 5 & 13 & 22 & 53 & 141 & 246 & 307 & 243 & 271 & 114 & 14 & 7 \\
\hline & & Max. & 26 & 47 & 104 & 136 & 301 & 507 & 763 & 468 & 644 & 292 & 101 & 92 \\
\hline & & Min. & 0 & 0 & 0 & 0 & 17 & 85 & 94 & 96 & 89 & 4 & 0 & 0 \\
\hline
\end{tabular}

Table A2. Crop data on planting date, length of growth stage and harvesting date of the crops of Bogura and Rajshahi districts under investigation

\begin{tabular}{|c|c|c|c|c|c|}
\hline \multirow[t]{2}{*}{ Crops } & \multirow{2}{*}{$\begin{array}{c}\text { Planting/ } \\
\text { Transplanting } \\
\text { date }\end{array}$} & \multicolumn{3}{|c|}{ Length of growth stage (day) } & \multirow[t]{2}{*}{ Harvesting date } \\
\hline & & development & mid-season & late-season & \\
\hline Aman & 1 August & 30 & 30 & 25 & 14 November \\
\hline
\end{tabular}




\begin{tabular}{|c|c|c|c|c|c|c|}
\hline Aus & 1 May & 20 & 30 & 20 & 20 & 30 July \\
\hline Boro & 17 January & 20 & 30 & 40 & 15 & 29 April \\
\hline Potato & 20 November & 20 & 25 & 40 & 15 & 18 February \\
\hline Wheat & 26 October & 10 & 20 & 45 & 25 & 4 February \\
\hline Pulses & 16 September & 20 & 30 & 40 & 20 & 5 January \\
\hline Sugarcane & 1 January & 30 & 60 & 180 & 95 & 1 January \\
\hline Vegetables & 15 November & 20 & 30 & 30 & 15 & 19 February \\
\hline Mustard & 20 November & 15 & 30 & 20 & 15 & 9 February \\
\hline
\end{tabular}

Table A3. Soil-types, initial soil-moisture content $\left(\mathrm{MC}_{\mathrm{ini}}\right)$, soil-moisture content at saturation $\left(\mathrm{MC}_{\mathrm{sat}}\right)$ and field capacity $\left(\mathrm{MC}_{\mathrm{FC}}\right)$, residual soil-moisture content $\left(\mathrm{MC}_{\mathrm{res}}\right)$, saturated hydraulic conductivity $\left(\mathrm{K}_{\mathrm{sat}}\right)$ and percolation rate for rice fields $\left(\mathrm{PER}_{\text {rice}}\right)$ used in estimating water requirements for Bogura and Rajshahi districts

\begin{tabular}{lcccc}
\hline Parameters & Loam & Clay & Clay loam & Heavy clay \\
\hline $\mathrm{MC}_{\text {ini }}$ & 0.2 & 0.25 & 0.27 & 0.298 \\
$\mathrm{MC}_{\text {sat }}$ & 0.35 & 0.52 & 0.52 & 0.55 \\
$\mathrm{MC}_{\mathrm{FC}}$ & 0.22 & 0.39 & 0.36 & 0.49 \\
$\mathrm{MC}_{\text {res }}$ & 0.04 & 0.24 & 0.21 & 0.35 \\
$\mathrm{~K}_{\text {sat }}(\mathrm{mm} / \mathrm{d})$ & 136.8 & 57.6 & 62.4 & 50.4 \\
$\operatorname{PER}_{\text {rice }}(\mathrm{mm} / \mathrm{d})$ & 1.0 & 1.0 & 1.5 & 0.5 \\
\hline
\end{tabular}

Table A4. Rooting depths, depletion factors, yield reduction factors and ponding depths of different crops used in in estimating water requirements for Bogura and Rajshahi districts

\begin{tabular}{lccccccc}
\hline Parameters & Stage & Rice_BR29 & Rice_Aman & Rice_Aus & Wheat & Potato & Other Robi \\
\hline \multirow{2}{*}{ Root depth (mm) } & ini & 500 & 1000 & 700 & 800 & 700 & 600 \\
& md & 1000 & 1000 & 700 & 1000 & 1000 & 600 \\
\hline \multirow{4}{*}{ Depletion factors } & ini & 0.2 & 0.6 & 0.1 & 0.55 & 0.4 & 0.45 \\
& mid & 0.2 & 0.6 & 0.1 & 0.55 & 0.4 & 0.45 \\
& end & 0.2 & 0.9 & 0.3 & 0.8 & 0.4 & 0.8 \\
\hline \multirow{4}{*}{ Yield reduction factors } & ini & 0.9 & 0.2 & 1.1 & 0.2 & 0.4 & 0.2 \\
& dev & 1.1 & 0.65 & 1.1 & 0.55 & 1.1 & 1.1 \\
& mid & 0.5 & 0.55 & 2.2 & 0.65 & 0.8 & 0.75 \\
& end & 0.33 & 0.25 & 0.33 & 0.35 & 0.4 & 0.2 \\
\multirow{4}{*}{ Ponding depth (mm) } & tot & 1.5 & 1.5 & 1.5 & 1.15 & 1.05 & 1.15 \\
& max & 100 & 100 & 100 & & & \\
& min & 10 & 10 & 10 & & & \\
\hline
\end{tabular}

\section{Copyrights}

Copyright for this article is retained by the author(s), with first publication rights granted to the journal.

This is an open-access article distributed under the terms and conditions of the Creative Commons Attribution license (http://creativecommons.org/licenses/by/4.0/). 